\title{
Missions, Charity, and Humanitarian Action in the Levant (19th-2oth Century)
}

\author{
Chantal Verdeil
}

\section{Introduction}

There is nothing new about the idea of continuity between the missionary apostolate and humanitarian action. Writing of the crisis of the Catholic missions at the time of colonial independence, some 15 years ago, Claude Prudhomme noted that the mid-2oth century marked the "end of an era and of the European missionary utopia [...]. Unless humanitarian intervention constitutes a last attempt to reactivate the missionary spirit".1

A missionary territory for many centuries, the Middle East is particularly fertile ground for these ideas in that it is seen as one of the cradles of European and Us humanitarian action. ${ }^{2}$ At the beginning of the 2000 , this area saw the emergence of large numbers of NGOs, usually seen as a sign of the vitality of "civil society" and as the outcome of the relative disengagement of the state from the social domain, in a context that was economically liberal and politically authoritarian. Hamit Bozarslan, for instance, sees NG o s as a "route whereby the authorities attempt to depoliticize the social or to promote charity as the only way to overcome economic and social problems of which they have washed their hands". ${ }^{3}$

Today, the idea that "Religion might have been instrumental in the establishment of humanitarianism, but it passed the torch to secularism" ${ }^{4}$ (via the NGO) is disputed: many missionary or religious organizations are very active

1 Claude Prudhomme, "Quand triomphe la mission: autopsie d'un succès," in Une appropriation du monde: Mission et Missions, XIXème-XXème siècles, ed. Claude Prudhomme (Paris: Publisud, 2004), 15 .

2 Davide Rodogno, Against Massacre, Humanitarian Interventions in the Ottoman Empire, 18151914: The Emergence of a European Concept and International Practice (Princeton: Princeton University Press, 2012).

3 Hamit Bozarslan, Sociologie politique du Moyen-Orient (Paris: La Découverte, 2011), 58.

4 Michael Barnett and Janice Gross Stein, "Introduction: The Secularization and Sanctification of Humanitarianism," in Sacred Aid: Faith and Humanitarianism, eds. Michael Barnett and Janice Gross Stein (Oxford: Oxford University Press, 2012), 3-36. 
in humanitarian work alongside NGO s with no religious affiliation: the former have not "passed the torch" to the latter. The process of secularization, if secularization there is, does not lead to an eradication of the religious actors, nor to a decline in their power to mobilize and their capacity to act. Rather than a passing of the baton, therefore, we need to think in terms of influence and explore the impact of missionaries on the development of humanitarian practices and law. If we reverse the perspective and look at the development of missionary practices, in particular since colonial independence, and at the influence of NGOS on their methods of operation, the transformation of certain missionary congregations (or at least of some of their activities) can be described as a "NGOization". For example, according to Louis Audet-Gosselin, the fact that the Catholic Church in Burkina Faso was able to maintain its influence in Burkinabé society is because it relied on the conversion of congregations to non-governmental organizations, as well as on the arrival of new congregations and NGO s. ${ }^{5}$

In the comparison between humanitarian organization and mission, research has primarily focused on the forms of their "charitable" or "humanitarian" action, on their ideals, on the bureaucratic or professional nature of their operations. ${ }^{6}$ Here, we wish to explore the material, and more specifically the financial, dimension of missionary activity, making this the subject of the invitation issued by Sarah Ben-Néfissa to researchers interested in NGO s: because NGO $\mathrm{s}$ are "intermediaries between funding agencies and populations", it is important "to study their 'social capital' and their networks of upward and downward relations". What image of the charitable activity of missionaries emerges if we look at their methods of funding? How do the missionaries use their social capital? Do they have access to "funding agencies"? Through what channels?

To answer these questions, this article first provides an overview of the humanitarian (charitable) action of the missionaries in the Middle East and in the Maghreb (Syria, Palestine, Egypt, Turkey, Algeria) during the golden age of the Christian missions to the Middle East (broadly the years 1880-1930), in order to highlight both its diversity and its spiritual and material character. It then examines the funding of these activities, which came not only from Europe and America, but also from substantially local, Christian but also Muslim, sources. Finally, it shows the genuine skills of the missionaries in "fundraising", know-how that was necessary to the maintenance and even more to the development of their charitable works.

5 Louis Audet-Gosselin and Marie Nathalie LeBlanc, Faith and Charity: Religion and Humanitarian Assistance in West Africa (London: Pluto Press, 2016).

6 Barnett, "Introduction," 7. 
In Christianity, Charity is a theological virtue, indissociably linked with the love of God and one's neighbour, spiritual and material. In France, until the beginning of the 19th century, the care of the poor (the sick, orphans, prisoners, the destitute) was undertaken by religious congregations. It gradually became more secular during the 19th century, under the description bienfaisance (corresponding to the English "do-gooding"). ${ }^{7}$ Through missionary activity, religious congregations continued to pursue charitable activities: even though not much used by the missionaries, who spoke of their poor, the word charity was a way to highlight the indissociably material and spiritual nature of their work. What role does charity play in the apostolate of the Christian missionaries? What is their attitude to poverty? Who are their poor?

In the 19th century, the work of the Christian missionaries in the Middle East was dominated by education and health. Schools, colleges, universities, dispensaries, hospitals occupied most of the personnel and received the majority of the resources of the missions. Educational and health institutions had a charitable dimension because they took in the "poor", although they were not solely attended by the most destitute sections of the local population. Alongside these institutions, other activities were more clearly charitable in nature: orphanages, shelters for prostitutes, the visiting of prisoners, support for unskilled workers. If we wish to explore the charitable dimension of the work of the Christian missionaries, we must begin by considering the population - whether destitute or marginal — they were addressing. The missionaries' day-to-day "charity" was aimed first of all at poor children, whether orphans or from poor families, the sick, prostitutes or domestic servants, unskilled male and female workers.

The Christian ministries founded several orphanages as part of their activities in the Middle East. This occurred particularly after the big humanitarian crises that affected the region (confrontations between Druze and Maronites in 1860, genocides and massacres during the First World War, expulsion of the Palestinians from the new state of Israel in 1948 ...). After 186o, the Jesuits founded a boys' orphanage at Bikfaya in Mount Lebanon while the Daughters of Charity opened a similar institution in Beirut, which was soon employing a weaver, a tailor, a cobbler, a carpenter, in order to "train good Christians and good workers who would later be capable of earning an honest living and sup-

7 Chrisitan Felkay, "Filles de la Charité et bureaux de bienfaisance parisiens (1796-186o)," in Des Filles de la Charité aux Soeurs de Saint-Vincent de Paul, quatre siècles de Cornettes, ed. Matthieu Bréjon de Lavergnée (Paris: Honoré Champion, 2016), 391-404. 
porting their families". 8 In Egypt, there was the Presbyterian Fowler Orphanage, named after its first donors, a Quaker couple, Esther and John Fowler, who offered \$8ooo to Margaret (Maggie) Smith (from the American Presbyterian mission) to found an orphanage. Managed by Margaret Smith until the 1920s, then by Ellen Barnes, it was home to some 30 children until the First World War. ${ }^{9}$

In Alexandria, the Salesians of Don Bosco opened an arts and crafts school in 1897 for "sons of the people" whom they sought to turn into "good Christians and honest workers". ${ }^{10}$ In 1901-1902, $20 \%$ of the pupils were orphans, 20 years later the figure was $50 \%$. The aim of the missionaries was to teach these "poor children" a trade, but also to dispense moral instruction:

To have intelligent, educated workers, confident in their future and convinced that it depends on their virtues, on their constancy in their work and a solid faith, is the desire of all those who have the good of society in their heart. This was the purpose of the establishment of the Don Bosco Institute in Alexandra. [...] Thus will be fulfilled the wishes of all the noble and generous people who, having in their heart the good of the country, which depends on the proper direction of the youth of different conditions, regretted the absence of an establishment that would take care of young people of humble origin, destined later on to occupy an honoured place within the working class. ${ }^{11}$

Poor children could also be admitted to the missionary schools through a system of equalization that made it possible to keep classes open for modest families thanks to the fees paid by families from a more comfortable social background. In Damascus, the Daughters of Charity school had a dual curriculum. To girls "whose parents were relatively well-off", the sisters taught French and Arabic, history, geography, arithmetic, music, and drawing. For poorer children,

8 "Letter from Sister Meyniel, Daughter of Charity," Bulletin de l'Oeuvre des Ecoles d'Orient, November 1883, 167-172.

9 Beth Baron, "Orphans and Abandoned Children in Modern Egypt," in Interpreting Welfare and Relief in the Middle East, eds. Nefissa Naguib and Inger Marie Okkenhaug (Leiden, Boston: Brill, 2008), 13-34.

10 Annalaura Turiano, "De la pastorale migratoire à l' enseignement technique, missionnaires italiens en Égypte: Les salésiens et l' enseignement professionnel (189o-1970)" (PhD diss., Aix-Marseille Université, Aix-en-Provence, 2016).

11 ASC $\mathrm{F}_{3} 8_{3}$, Arts and crafts schools. Origins and objectives of the Institute, cited by Annalaura Turiano, "État, réformistes et philanthropes: Les enjeux de l'enseignement professionnel en Égypte au tournant du Xx ${ }^{\mathrm{e}}$ siècle," Histoire de l'Éducation 148 (2018). 
"all those whose families were not so concerned with education", the general education was less extensive, leaving more space for manual skills "proper to their condition".12

The missionaries also often ran hospitals, which cared for patients from all social categories. At the end of the 19th century, the Anglican missionary hospital in Hebron, founded in 1891, was the district's only hospital, and would remain so right through to the end of the British Mandate. This hospital not only admitted the poorest populations but was also intended as a place for activities of evangelization. These two objectives, caring for the sick and evangelizing society, sometimes proved irreconcilable. The accusations diminished after 1846 when the authorities found in favour of the nuns, but they continued to circulate. ${ }^{13}$

Other categories of population, whether marginal or working class, were also the target of the missionaries' apostolate. In the middle of the century in Cairo, the Filles de la Charité du Bon Pasteur d'Angers had created a "charity for negresses", which took in slaves from Nubia, Sudan, or other regions of Africa, freed them and gave them a "Christian education". Many of them, "maltreated by the traders" died "in the arms of the nuns". This activity was subsequently passed on to the Soeurs de Saint-Joseph de l'Apparition. ${ }^{14}$ On their arrival in Beirut, the Daughters of Charity visited the city's prison, where typhoid was rife. They were usually accompanied by a doctor responsible for providing care. A postcard published by the Capuchin mission in Syria during the interwar period also illustrates their work in favour of the poor, the "destitute", through the distribution of food (Figure 1.1).

In Tripoli, the Daughters of Charity built a silk mill where they hoped to train some of the girls who would subsequently work in other similar institutions once established. Male workers were also the target of a "congregation" founded by a Jesuit priest, Father Fiorovich (1818-1898), at the end of the 19th

12 "Letter from Sister Marie, Daughter of Charity, Superior of the Saint Joseph house in Damas," Bulletin de l'Oeuvre des Ecoles d'Orient, January 1887, 15-17.

13 Claire Fredj, "Une présence hospitalière en territoire colonial, les Filles de la Charité en Algérie (1842-1962)," in Des Filles de la Charité aux Soeurs de Saint-Vincent de Paul, quatre siècles de Cornettes, ed. Matthieu Bréjon de Lavergnée (Paris: Honoré Champion, 2016), 456-457.

14 L. Cosnier, Le Bon-Pasteur d'Angers en Égypte: L'œuvre des Écoles d'Orient (Angers: Librairie Lachèse et Dolbeau, 1882), 7; Beth Baron, "Liberated Bodies and Saved Souls: Freed African Slave Girls and Missionaries in Egypt," in African Communities in Asia and the Mediterranean: Identities between Integration and Conflict, ed. Ehud R. Toledano (Halle: Max Plank Institute, 2011). 
century, the congregation of Our Lady of the Seven Sorrows, which brought together the city's "humble working folk", porters, shoe shiners, print workers ... Its recruitment was strictly confessional: the aim was to give spiritual support to an often migrant male Catholic population, whose rootlessness, poverty, and social precariousness were seen by the monks as a threat to faith and morality. The congregation offered or imposed on them exercises in piety (masses, sermons, pilgrimages ...) while at the same time introducing forms of solidarity between its members. The city was divided into four districts, each with its inspectors or delegates responsible for visiting the sick, providing aid to the needy, smoothing over any quarrels and monitoring the congregations by dissuading them, for example, from sending their children to schools run by Protestant missionaries. ${ }^{15}$

This rapid outline of the missionaries' charitable activities does not offer a comprehensive overview of all the missionaries' work in the Middle East. It ignores their work in providing exceptional relief, distributed in times of crisis: our aim here was to look at their day-to-day activities. However, it shows the diversity of their targets: men, women, children or young people (girls or boys), the sick and the healthy. The elderly seem relatively absent, perhaps because there were few of them in the hospitals: the European or American clergy were above all interested in the young, who it is true formed the majority of the population. These charitable activities bear witness to economic activity and demographic changes in the region: the development of the port of Beirut, which attracted numerous migrants, the cultivation of silk in Mount Lebanon, the high death rate everywhere, the persistence of slavery (especially in Egypt), the development of healthcare and educational institutions. In the eyes of the missionaries, relief was not only material, but also spiritual: charity was a moral and religious task.

\section{The Funding of Missionary Charity: Local and International Funding}

How was this charity funded? Apart from the diversity of the congregations, Catholic or Protestant, is it possible to outline a general pattern of activity? In order to do this, we need to look at the operation of the missions and their funding. However, it has to be recognized that the question of the funding of the

15 Michel Jullien sj, La nouvelle mission de la Compagnie de Jésus en Syrie, 1831-1895 (Tours: Imprimerie Mame et Fils, 1899). 
missions has not attracted much scholarly attention. In French historiography, which focuses above all on Catholic missions, these financial questions have cast light on the support given by the French government and notably the anticlerical Republic to the missionary charities, ${ }^{16}$ whereas in the history of the Protestant missions, this aspect-essential as it is—usually remains in the background. Nonetheless, research has highlighted the diversity of these sources of revenue, which reflects both the local grounding of the missions and their ability to maintain close links with potential donors in their countries or with their home Churches. On the subject of the Daughters of Charity in Algeria, Claire Fredj notes that their resources were extremely varied: "investments, income from land, profits from sewing rooms, boarding houses, lessons, income from the work of the nuns, especially their payment [as nurses in civilian or military hospitals]". ${ }^{17}$

It has to be said that the available archives do not always make life easy for historians. Even those of the Society of Jesus, albeit known as a formidable bureaucracy, do not tell us the precise budget of the Jesuit mission in Syria, and in the absence of information it is not certain that the superiors of the order themselves had an accurate and reliable idea of it. A precise study of its operation shows that many of the clergy enjoyed a great deal of autonomy and approached donors via their own networks, in other words short-cutting their hierarchy which was, at least theoretically, supposed to centralize all requests and receive all contributions before distributing the money collected among everyone. ${ }^{18}$ From the example of the Jesuit mission in Syria, combined with other research, it is nevertheless possible to clarify the financial management of a missionary enterprise. What were its sources of revenue? How did it obtain them?

These sources of revenue can be divided into several categories, depending on their geographical origin and the status of the donors. With regard to geography, we will differentiate between revenues from local society (donations, school fees, sales of books or leaflets) and those originating from abroad, from Europe or the United States. With regard to the donors, we can differentiate between individuals and the states that supported the missions or contributed to their funding.

16 Notably Patrick Cabanel, Une France en Méditerranée (Paris: Créaphis, 2006); Jacques Thobie, Les intérêts culturels français dans l'Empire ottoman finissant (Leuven: Peeters, 2008).

17 Fredj, "Une présence hospitalière en territoire colonial," 452.

18 Chantal Verdeil, La mission jésuite du Mont-Liban et de Syrie (1830-1864) (Paris: Les Indes Savantes, 2011). 
We will begin by looking at the local dimension of the funding of the missions and of their charitable works. Within the missions, budgets were not clearly separated, and a flourishing activity could be used to fund a less lucrative one. The silk mill that the Daughters of Charity ran in Tripoli was also to enable them to "support [their] internal children".19

In the Jesuit mission in Syria, the printing press generated profits that were reallocated to proselytizing activities and to the small schools. Nonetheless, these schools were very largely financed by the families of the students, who saw education as a new form of investment. In the most modest classes, for example in Mount Lebanon, some of this funding came in kind, with the locally recruited teachers being compensated by the villagers in the form of accommodation, food, and sometimes a few clothes (in particular shoes). In this case, the role of the Jesuits who ran this network of schools was not to teach but to supervise the operation of the classes: they made sure that both parties fulfilled their undertakings and acted as intermediaries to resolve disputes in the event of conflict. ${ }^{20}$ In the urban centres, where the missionaries taught in the classes, part of the funding also came from the families. In 1896, the revenue side of the budget of the primary classes at Saint-Joseph University, a Jesuit institution which-despite its name-mainly educated children aged 8 to 18 , consisted chiefly of school fees paid by the pupils. The cost of full board in that case was 600 francs, but there were reductions available for students on half board and day pupils. In all, the fees paid by the families of the students amounted to 113 ,ooo francs, $82 \%$ of the institution's revenues (elementary, primary, and secondary levels). Within this educational establishment, as in most of the Catholic missionary schools, there was a system of equalization that was used to pay for the schooling of pupils from the poorest backgrounds. The "paying" pupils paid for the "free" pupils. ${ }^{21}$ Moreover, this system functioned along confessional lines: discounts were never granted to Muslims or non-Catholic Christians. Muslims and Greek Orthodox families thus indirectly financed the schooling of the poorest Catholics.

This "solidarity" on the part of the socially well-to-do did not stop at the school gates. The missionaries knew how to use their networks to help pupils

\footnotetext{
19 "Letter from Sister Ramel, Daughter of Charity, Tripoli in Syria, 1o March 1882," Bulletin de l'Oeuvre des Ecoles d'Orient, July 1882, 334-336.

20 Chantal Verdeil, "La classe 'sous le chêne' et le pensionnat: Les écoles missionnaires en Syrie (186o-1914) entre impérialisme et désir d'éducation," Outre-Mers: Revue d'histoire 334-335 (June 2007): 197-222.

21 Jérôme Bocquet, Missionnaires français en terre d'islam, Damas 1860-1914 (Paris: Les Indes savantes, 2005).
} 
obtain employment. So the Christian Brothers of Bethlehem were able to mobilize the town's notables, even "dissidents" -in other words Greek Orthodox - to the benefit of poorer children, often from Catholic backgrounds. This is what Brother Onésime explained to his superiors in order to justify the links that the mission maintained with these non-Catholic communities (who were therefore "suspect" in the eyes of his superiors):

Another consideration which is not of the same order but is of value in that it relates to charity: in general, our Catholics are poor and, since the dissidents belong to more influential families, and quickly obtain a situation, they take great pleasure in responding to the requests of their educators in favour of young Catholics in search of a humble position ... I can cite thousands of examples of this. ${ }^{22}$

Here, the missionary schools redistributed money and other social resources from the wealthier communities towards the poorer, and the monks established and supervised forms of solidarity between pupils from different backgrounds. Their role was very similar to that of the charitable congregations in Europe, such as the Daughters of Charity in Paris, which approached high society women to come to the aid of the poor in their care. ${ }^{23}$ More generally, local believers provided a source of funding or gave material aid to the missionaries and their charitable works. For the Jesuit mission in Syria, the sources mention - without further detail—donations in kind and in particular land for rent. They also mention Nicolas Comati, from whom the Jesuits rented a house to house orphans after the 186o massacre, as a "great benefactor of Fr. Fiorovich". 24

In admittedly very exceptional circumstances, the Ottoman state contributed to the funding of missionary activity. After the events of 1860, the Catholic congregations - some of whom had suffered heavily from the violence and

22 "Admission of dissidents into our schools," notes by Brother Onésime, visitor, Bethlehem, August 11, 1910, cited by Karène Summerer-Sanchez, "Action sanitaire et éducative en Palestine des missionnaires catholiques et anglicans," in Missions chrétiennes en terre d'Islam, Moyen-Orient, Afrique du Nord (XVII ${ }^{e}-X X^{e}$ siècles), anthologie de textes missionnaires, ed. Chantal Verdeil (Turnhout: Brepols, 2013), 231-282.

23 Sarah A. Curtis, "Filles de la Charité et assistance locale, l' exemple de la paroisse SaintMédard à Paris au XIxe siècle," in Des Filles de la Charité aux Soeurs de Saint-Vincent de Paul, quatre siècle de Cornettes, ed. Matthieu Bréjon de Lavergnée (Paris: Honoré Champion, 2016), 405-421.

Louis Jalabert, Jésuites au Proche-Orient (Beirut: Dar el-Machreq, 1987), 6o-61. 
destruction-received substantial compensation: it amounted in all to 202,000 francs in compensation for the "blood spilt" and "damage" suffered in Zahlé. ${ }^{25}$ This sum, paid in two instalments, 123,000 francs in October $1862,{ }^{26}$ and the rest at the beginning of 1863 , was twice as large as the amount allocated by the relief committees funded by the OEuvre des Écoles d'Orient (Society of Eastern Schools). ${ }^{27}$ While this compensation was partly directed to charitable works, in particular for orphans, it provided the opportunity for exceptional investments that the mission's ordinary funds alone would not have financed: the purchase of new buildings, the refurbishment and extension of residences.

These local resources were supplemented by revenues from outside, from France, Europe, or the United States. This was the case for Beirut's Syrian Protestant College, which also obtained part of its funding from the school fees paid by pupils. Otherwise, this funding came from American foundations and private donors, most of whom were members of the Board of Trustees, honoured by the institution through the names assigned to its buildings. William E. Dodge (1805-1883), one of the first of these donors, had made his fortune in the railways, timber, copper mining, and real estate, and partly controlled the New York Stock Exchange. ${ }^{28}$ Between them, the sources provide a clue to the family ties that made the institution a family affair: so the chapel built by the Syrian Protestant College in 1891 was attributable to the generosity of Elbert B. Monroe, brother-in-law of Frederick Marquand who had himself financed the construction of a building 10 years earlier. ${ }^{29}$

For its part, Saint-Joseph University was the beneficiary of substantial French public funds, which financed the medical faculty it opened in 1883 . At the end of the 19th century, the subsidy paid by the government was in the region of 100,000 francs, ${ }^{30}$ for a faculty which at the time had slightly over a hundred students. ${ }^{31}$ This colossal commitment and the French government's support for myriad missionary activities has prompted some to highlight, quite

25 Archives libanaises de la Compagnie de Jésus (ALSI), 8A6, Letter from Fr. Monnot to Fr. Serre, 1876 .

26 Archives romaines de la Compagnie de Jésus (ARSI), Syr 1004, II, 18, Letter from Fr. Canuti to Fr. Beckx, Beirut, October 23, 1862.

27 ARSI, Syr, 1004, 25, Letter from Fr. Canuti to Fr. Beckx, Beirut, October 16, 1863.

28 Alexandra Kobiljski, "Un modèle américain? Les collèges protestants de Beyrouth et Kyoto, 186o-1975," Monde(s) 6 (2014): 187.

29 Stephen B.L. Penrose jr, That They May Have Life (Beirut: American University of Beirut, 1970), 55 .

30 ARSI, Syr 1006, v, 20, letter from Fr. Edde to Father Superior, Beirut, January 27, 1896.

31 Archives françaises de la Compagnie de Jésus (AFSI), Coll Prat, T. 27, information on the Beirut Faculty given confidentially to the Father Provincial by Fr. Cattin (1895). 
correctly, the "immaterial imperialism of language" 32 promoted by the France of the Third Republic. When assigned to each congregation's budget, however, these sums were not so substantial: in order to maintain and develop their activities, the missionaries also relied — as we have seen-on the support of the local populations. They also called on private charity, both in Europe and the USA.

Several works of French historiography on the missions have focused on the missionary charities, such as the charity of the Propagation of the Faith which, from its foundation in the early 1820 , collected considerable sums for all the overseas Catholic missions. ${ }^{33}$ In 1856, just after the Crimean War, a new organization was founded, the OEuvre des Écoles d'Orient (Society of Eastern Schools) which collected funds specifically intended for the missions and for the Churches established in the Orient. In each case, the principle was the same: the charities published letters from the missionaries, whose stories encouraged the faithful to donate. Modest while these donations might be, they were also very numerous, and ultimately generated colossal amounts. From the 1840 os onwards, the revenues of the charity of the Propagation of the Faith underwent very rapid growth, rising from 306,717.42 francs in $183^{1}$ to 4,702,227.21 francs thirty years later. They passed the 5 million threshold in $1864{ }^{34}$ For the Near East, the intercommunal violence that engulfed Mount Lebanon then Damascus, stimulated donations: in November 1861, the OEuvre des Écoles d'Orient collected more than 2 million francs for the Oriental Christians. ${ }^{35}$ Its ordinary budget was significantly smaller, but every year the Catholic missionary organizations and the Catholic churches of the East received subsidies from it.

It would be a mistake to believe that these sums of money came to the missionary organizations without any effort on their part. On the contrary, the Catholic missionaries were skilled in implementing strategies for collecting money, as the example of the Jesuit mission in Syria shows spectacularly.

32 Cabanel, Une France en Méditerranée, 9-28; Thobie, Les intérêts culturels français dans l'Empire ottoman finissant.

33 Richard Drevet, "L' oeuvre de la Propagation de la Foi et la propaganda missionnaires au XIXe siècle," in Une appropriation du monde: Mission et Missions, XIXème-XXème siècles, ed. Claude Prudhomme (Paris: Publisud, 2004), 23-43.

Archivio Storico di Propaganda Fide (APF), fasc. no. 24, April 1831; vol. 32, 186o, 153-200; vol. 37, 1865, 163-208.

35 "Aux membres de l'CEuvre des Ecoles d'Orient," Bulletin de l'Oeuvre des Ecoles d'Orient no. 13, November 1861, 1-6. 
The letters published by the "missionary societies", the Association for the Propagation of the Faith, and the CEuvre des écoles d'Orient, were written specifically for this purpose, or more precisely were inspired by letters from missionaries that were usually rewritten for the readers of the Bulletins of these societies: their purpose was to thank the donors, to report on the activities of the missionaries, their progress (in this case, support for the Christians of the Eastern Catholic Churches, more rarely conversions), and to solicit donations: for this reason, most of the letters mention the needs of the different missionary charities (large numbers of pupils and patients, the poverty of the population ...). In the 2oth century, many congregations published postcards to illustrate their activities and solicit donations.

For example, this photograph (Figure 1.1) shows a Capuchin missionary distributing food. The caption on the verso says: "The offerings for the Syria Missions are received at the Procure of the Missions to the Levant 14, rue des Tourelles, Lyon (St Just)."36

In the Jesuit mission in Syria, one priest had the specific task of collecting funds. This was the "procurer". Two monks distinguished themselves particularly in this role, Fr. Amédée of Damas (1821-1903), procurer between 1859 and 1869 (then founder of the Armenia mission in 1880), and Fr. Louis Jalabert (1877-1943), unofficial representative of the Catholic missions to the French government during the period of the mandate. The son of Louis XVIII's Minister of Foreign Affairs, brought up alongside the Count of Chambord (heir to the throne of France), Fr. de Damas placed his connections at the service of the Society and its missions. During several journeys in the 186os, he solicited the generosity of the European aristocracy. In 1862, he travelled to Paderborn, to Cologne and then to Vienna, where he met the Emperor, his mother the Archduchess Sophie, the Cardinal of Vienna, and the papal Nuncio before delivering the Lent sermon in the Church of the Teutonic Knights. The Society of the Immaculate Conception of Vienna offered to send scholarships to the seminary-college that the Jesuits ran in Mount Lebanon, while the Committee of the Holy Sepulchre of the Cities of the Rhine (Paderborn, Cologne) and of Bavaria (Munich) sent donations several times: 3,00o thalers (12,00o francs) in $1861,20,000$ francs in $1862 .{ }^{37}$

$36 \quad$ Postcard, Collection Gélébart.

37 AFsI, Coll Prat, vol. 9, letter from Fr. Bourquenoud to Fr. Gautrelet, Paderborn (May 19, 1861), 993-994. 


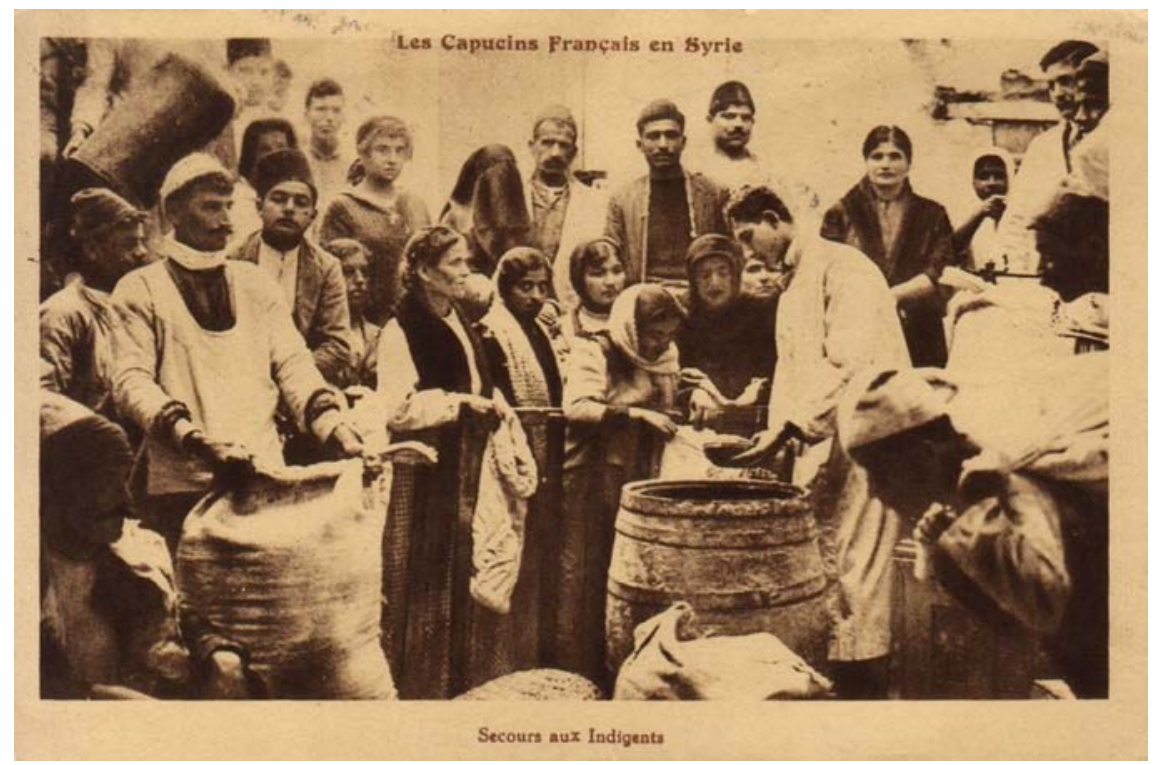

FIGURE 1.1 Postcard, Collection Gélébart, private collection.

Despite his name, which suggests an association with the Legitimist movement that in France supported the former Bourbon dynasty, Fr. de Damas approached the French Imperial government which, at the time (before 186o), was not providing financial support for the mission. Here again, he obtained scholarships for the Jesuit students: this connection began a policy of collaboration which reached its apogee in the joint creation of the Faculty of Medicine at Saint-Joseph University which, as we have seen, was almost entirely funded by the French government of the Third Republic.

In order to maintain this support, the Jesuits had to sustain such connections, which could be threatened by political change. In this respect, the role of Fr. Lucien Cattin (1851-1929), rector of Saint-Joseph and Chancellor of the Faculty of Medicine, was essential at the turn of the century and following the rise to power of the Left-Wing Block, with its highly anticlerical programme. His letters describe him in Paris, moving from ministerial offices to dinners in town, in search of people able to introduce him to ministers or to support his cause, at a time when the election of numerous anticlerical MPs was threatening the French government's support for the Catholic missions. Thanks to his contacts and connections, Fr. Cattin was able to save the most important things: the college scholarships were discontinued in 1906, but the subsidy for the Faculty of Medicine was maintained and even increased.

Other methods of collecting money could be used: for example, the construction of Beirut's Saint-Joseph University was largely financed by funds col- 
lected from ... American Catholics by Fathers Monnot (1831-1898) and Pailloux (1814-1887), respectively superior of the mission and architect of the building. In 1871, the two men travelled to England, then to the United States, where they spent almost three years collecting the money for the construction of the college. They returned to Beirut in the autumn of 1874 , when work began: the University opened its doors a year later. ${ }^{38}$

\section{5}

\section{Conclusion}

Catholic and Protestant missionaries in the Levant were deeply involved in charitable activities. This simple fact justifies considering their action in the light of that of NGOS. Here I aim to highlight the financial dimension of this charitable work.

The financing of the missions, and in particular their most charitable activities relied on the use of various fundraising techniques that can be analysed very well using the vocabulary employed by modern fundraisers: appeal to "small" donors, verbally and in writing, sermons followed by collections, and the letters in the Bulletins, approaches to "sponsors" although this was not a term used at the time, who could be political or society figures or organizations, requests for subsidies from public actors, as was the case for the Jesuit mission in Syria with the governments of the Second Empire then of the Third Republic.

There was nothing "spontaneous" or improvised about this, as evidenced by the care with which the letters were written or rewritten for the missionary bulletins, the appointment in certain religious congregations of one person particularly responsible for fundraising, the capacity to maintain relations with generous sponsors or public institutions.

The examination of missionary resources highlights different financial circuits, some of them spanning seas and oceans, from Europe or the United States to the Middle East, others with a local dimension. At the centre, the missionaries orchestrated the flow of funds at these different levels: their charitable works were the outcome both of the investment of sums collected overseas and of the redistribution of wealth within local societies.

Finally, these financial circuits highlight their ability to mobilize their social capital derived from their individual, political, or religious networks. They might rely on family support (as we have seen for the American Mission in Beirut), on personal relationships with politicians and political officials (for

38 Jullien sj, La nouvelle mission de la Compagnie de Jésus en Syrie, 47-50. 
instance for the Jesuits) and on a sectarian network (Catholic for the Jesuits who found support from American Catholics to finance their new College). The missionaries' knowledge of local societies and their experience of the local field are often highlighted to allow comparisons with humanitarian organizations. But their skills in raising funds were also crucial for the improvement of their activities, as they are for NGO s involved in humanitarian actions today.

\section{Bibliography}

Archives françaises de la Compagnie de Jésus, AFSI. Coll Prat, vol. 9, letter from Fr. Bourquenoud to Fr. Gautrelet, Paderborn (May 19, 1861): 993-994.

Archives françaises de la Compagnie de Jésus, AFsı. Coll Prat, T. 27, information on the Beirut Faculty given confidentially to the Father Provincial by Fr. Cattin (1895).

Archives libanaises de la Compagnie de Jésus, ALSI. 8A6, letter from Fr. Monnot to Fr. Serre (1876).

Archives romaines de la Compagnie de Jésus, ARSI. Syr 1004, II, 18, letter from Fr. Canuti to Fr. Beckx, Beirut (October 23, 1862).

Archives romaines de la Compagnie de Jésus, ARSI. Syr, 1004, 25, letter from Fr. Canuti to Fr. Beckx, Beirut (October 16, 1863).

Archives romaines de la Compagnie de Jésus, ARSi. Syr 1006, v, 2o, letter from Fr. Edde to Father Superior, Beirut (January 27, 1896).

Archivio Storico di Propaganda Fide (APF). Fasc. no. 24, April 1831; vol. 32, 186o, 153-200; vol. 37, 1865, 163-208.

Audet-Gosselin, Louis, and Marie Nathalie LeBlanc. Faith and Charity: Religion and Humanitarian Assistance in West Africa. London: Pluto Press, 2016.

Barnett, Michael, and Janice Gross Stein. "Introduction: The Secularization and Sanctification of Humanitarianism." In Sacred Aid: Faith and Humanitarianism, edited by Michael Barnett and Janice Gross Stein, 3-36. Oxford: Oxford University Press, 2012.

Baron, Beth. "Orphans and Abandoned Children in Modern Egypt." In Interpreting Welfare and Relief in the Middle East, edited by Nefissa Naguib and Inger Marie Okkenhaug, 13-34. Leiden, Boston: Brill, 2008.

Baron, Beth. "Liberated Bodies and Saved Souls: Freed African Slave Girls and Missionaries in Egypt." In African Communities in Asia and the Mediterranean: Between Integration and Conflict, edited by Ehud R. Toledano, 215-235. Halle: Max Plank Institute, 2011.

Ben-Néfissa, Sarah. "ONG, gouvernance et développement dans le monde arabe." Gestion des Transformations Sociales MOsT, Document de discussion, no. 46 (2000). http://www.unesco.org/most/nefissa.html. 
Bocquet, Jérôme. Missionnaires français en terre d'islam, Damas 1860-1914. Paris: Les Indes savantes, 2005 .

Bozarslan, Hamit. Sociologie politique du Moyen-Orient. Paris: La Découverte, 2011.

Bulletin de l'Oeuvre des Ecoles d'Orient, no. 13. "Aux membres de l' CEuvre des Ecoles d'Orient." November 1861, 1-6.

Bulletin de l'Oeuvre des Ecoles d'Orient. "Letter from Sister Ramel, Daughter of Charity, Tripoli in Syria, 10 March 1882." July 1882, 334-336.

Bulletin de l'Oeuvre des Ecoles d'Orient. "Letter from Sister Meyniel, Daughter of Charity." November 1883, 167-172.

Bulletin de l'Oeuvre des Ecoles d'Orient. "Letter from Sister Marie, Daughter of Charity, Superior of the Saint Joseph house in Damas." January 1887, 15-17.

Cabanel, Patrick, ed. Une France en Méditerranée. Paris: Créaphis, 2006.

Collection Gélébart, private collection. Postcard.

Cosnier, L. Le Bon-Pasteur d'Angers en Égypte: L'œuvre des Écoles d'Orient. Angers: Librairie Lachèse et Dolbeau, 1882 .

Curtis, Sarah A. "Filles de la Charité et assistance locale, l' exemple de la paroisse SaintMédard à Paris au XIXe siècle." In Des Filles de la Charité aux Soeurs de Saint-Vincent de Paul, quatre siècle de Cornettes, edited by Matthieu Bréjon de Lavergnée, 405-421. Paris: Honoré Champion, 2016.

Drevet, Richard. "L'oeuvre de la Propagation de la Foi et la propagande missionnaire au XIXe siècle." In Une appropriation du monde: Mission et Missions, XIXème-XXème siècles, edited by Claude Prudhomme, 23-43. Paris: Publisud, 2004.

Felkay, Chrisitan. "Filles de la Charité et bureaux de bienfaisance parisiens (1796-186o)." In Des Filles de la Charité aux Sours de Saint-Vincent de Paul, quatre siècles de cornettes, edited by Matthieu Bréjon de Lavergnée, 391-404. Paris: Honoré Champion, 2016.

Fredj, Claire. "Une présence hospitalière en territoire colonial, les filles de la Charité en Algérie (1842-1962)." In Des Filles de la Charité aux Sours de Saint-Vincent de Paul, quatre siècles de cornettes, edited by Matthieu Bréjon de Lavergnée, 446-474. Paris: Honoré Champion, 2016.

Jalabert, Louis. Jésuites au Proche-Orient. Beirut: Dar el-Machreq, 1987.

Jullien, Michel sj. La nouvelle mission de la Compagnie de Jésus en Syrie, 1831-1895. Tours: Imprimerie Mame et Fils, 1899.

Kobiljski, Alexandra. "Un modèle américain? Les collèges protestants de Beyrouth et Kyoto, 186o-1975." Monde(s) 6 (2014): 171-193.

Penrose, Stephen B.L.jr. That They May Have Life. Beirut: American University of Beirut, 1970.

Prudhomme, Claude. “Quand triomphe la mission: autopsie d' un succès.” In Une appropriation du monde: Mission et missions, XIXème-XXème siècles, edited by Claude Prudhomme, 5-15. Paris: Publisud, 2004. 
Rodogno, Davide. Against Massacre, Humanitarian Interventions in the Ottoman Empire, 1815-1914: The Emergence of a European Concept and International Practice. Princeton: Princeton University Press, 2012.

Summerer-Sanchez, Karène. "Action sanitaire et éducative en Palestine des missionnaires catholiques et Anglicans." In Missions chrétiennes en terre d'Islam, MoyenOrient, Afrique du Nord (XVII $I_{-X X}^{e}$ siècles), anthologie de textes missionnaires, edited by Chantal Verdeil, 231-282. Turnhout: Brepols, 2013.

Thobie, Jacques. Les intérêts culturels français dans l'Empire ottoman finissant. Leuven: Peeters, 2008.

Turiano, Annalaura. "De la pastorale migratoire à l' enseignement technique, missionnaires italiens en Égypte: Les salésiens et l'enseignement professionnel (189o1970)." PhD diss., Aix-Marseille Université, Aix-en-Provence, 2016.

Turiano, Annalaura. "État, réformistes et philanthropes: Les enjeux de l' enseignement professionnel en Égypte au tournant du $\mathrm{Xx}^{\mathrm{e}}$ siècle." Histoire de l'Éducation 148 (2018): 41-70.

Verdeil, Chantal. “Travailler à la renaissance de l' Orient chrétien: Les missions latines en Syrie (1830-1945)." Proche-Orient Chrétien 51, nos. 3-4 (2001): 267-316.

Verdeil, Chantal, ed. Missions chrétiennes en terre d'Islam, Moyen-Orient, Afrique du Nord (XVII ${ }^{e}-X X^{e}$ siècles), anthologie de textes missionnaires. Turnhout: Brepols, 2013. Verdeil, Chantal. La missionjésuite du Mont-Liban et de Syrie (1830-1864). Paris: Les Indes Savantes, 2011.

Verdeil, Chantal. "La classe 'sous le chêne' et le pensionnat: les écoles missionnaires en Syrie (186o-1914) entre impérialisme et désir d'éducation." Outre-Mers: Revue d'histoire, 334-335 (June 2007): 197-222. 